JURNALYOGA DAN KESEHATAN

JURUSAN YOGA KESEHATAN

FAKULTAS BRAHMA WIDYA

IHDN DENPASAR
Vol. 3 No. 2 September 2020

ISSN : 2621-0185 (Cetak)

ISSN : 2722-9440 (Online)

http://ejournal.ihdn.ac.id/index.php/jyk

\title{
Manfaat Loloh Don Cemcem dalam Sistem Kesehatan Tradisional
}

\author{
I Gede Sutana \\ Sekolah Tinggi Agama Hindu Negeri Mpu Kuturan Singaraja \\ email: sutanagde@gmail.com
}

Diterima tanggal 9 Agustus 2020, diseleksi tanggal 16 Agustus 2020, dan disetujui tanggal 28 Agustus 2020

\begin{abstract}
Complex problems in people's lives in the global era often cause psychological pressure which subsequently causes various disturbances in the system of human body which eventually lead to various illness. In order to return to their health level, people are in their quest for diverse alternative health medications which have minimal side effects, one of which is back to nature by consuming traditional medicine. Traditional medicine has been familiar with the life of the Indonesian people, including the Balinese in particular. In Bali, there is a traditional health system which still exists in the community known as Usadha. In Usadha, there are various types of treatment, one of which is often used by the Balinese, namely medicinal herbs or the Balinese people often call it loloh. The Republic of Indonesia Minister of Health Regulation No. 61 of 2016 concerning Empirical Traditional Health Services and the existence of the Governor of Bali Regulation No. 55 of 2019 concerning Balinese Traditional Health Services have caused loloh to revive. Loloh is now not only consumed by the local people, but has also been consumed by foreign tourists who visit Bali. One of the prima donna is loloh don cemcem which is sourced from kecemcem leaves (Spondias pinnata (Lf) Kurz). The process of making loloh don cemcem follows the traditional serving pattern with the intention that by consuming it, people will get various benefits, especially in the aspect of physical health.
\end{abstract}

Keywords: Loloh Don Cemcem, Traditional Health Systems

\section{ABSTRAK}

Problematika yang kompleks dalam kehidupan masyarakat di era global kerap kali menimbulkan tekanan psikis yang kemudian menyebabkan berbagai gangguan pada sistem tubuh manusia yang akhirnya memunculkan penyakit. Guna kembali mencapai taraf kesehatannya, masyarakat mencari berbagai alternatif kesehatan yang minim efek samping, salah satunya adalah kembali ke alam (back to nature) dengan mengkonsumsi obat tradisional. Pengobatan tradisional sejak dahulu telah akrab dengan kehidupan masyarakat Indonesia termasuk masyarakat Bali pada khususnya. Di Bali terdapat sistem kesehatan tradisional yang hingga kini masih eksis di tengah-tengah masyarakat yang dikenal dengan nama Usadha. Di dalam Usadha terdapat berbagai jenis pengobatan, salah satunya yang sering digunakan oleh masyarakat Bali yaitu pengobatan dengan ramuan atau masyarakat Bali sering menyebutnya dengan istilah loloh. Adanya Peraturan Menteri Kesehatan RI No. 61 tahun 2016 tentang Pelayanan Kesehatan Tradisional Empiris serta adanya Peraturan Gubernur Bali No.55 tahun 2019 tentang Pelayanan Kesehatan Tradisional Bali menyebabkan loloh kembali naik daun. Loloh kini tidak hanya dikonsumsi oleh masyarakat lokal, tetapi sudah dikonsumsi oleh wisatawan mancanegara yang berkunjung ke Bali. Salah satu loloh yang menjadi primadona adalah loloh don cemcem yang bersumber dari daun kecemcem (Spondias pinnata $(L f)$ Kurz). Proses pembuatan loloh don cemcem mengikuti pola penyajian secara tradisional sehingga dengan mengkonsumsinya akan diperoleh berbagai manfaat khususnya pada aspek

kesehatan fisik.

Kata Kunci: Loloh Don Cemcem, Sistem Kesehatan Tradisonal 


\section{PENDAHULUAN}

Kesehatan merupakan sesuatu yang sangat berharga, bahkan kesehatan lebih berharga daripada harta. Bayangkan saja ketika sakit, makan apapun terasa tidak enak, badan terasa tidak enak, dan harta pun bisa habis untuk berobat. Begitu pentingnya kesehatan bagi kehidupan manusia, sehingga tubuh ini tetap terjaga dalam kondisi yang diharapkan. Pengaruh sosial budaya dalam masyarakat memberikan peranan penting dalam mencapai derajat kesehatan yang baik. Perkembangan sosial budaya dalam masyarakat merupakan suatu tanda bahwa masyarakat dalam suatu daerah tersebut telah mengalami suatu perubahan dalam proses berfikir sehingga akan melahirkan kebudayaan atau kultur dapat membentuk kebiasaan dan respons terhadap kesehatan.

Di era revolusi industri 4.0, berbagai kemudahan sudah didapatkan oleh masyarakat. Hal ini dapat terlihat dari masyarakat yang akrab dengan televisi, telepon genggam, komputer dan internet serta peralatan elektronik lainnya yang menjamin berbagai kemudahan dalam aktifitas manusia. Bepergian kini terasa lebih mudah dengan adanya alat transportasi yang makin canggih, layanan kesehatan juga lebih cepat dengan mempergunakan sistem multimedia. Dari berbagai layanan tersebut, masyarakat sangat merasakan berbagai kemudahan. Akan tetapi, dampak negatif yang ditimbulkan oleh berbagai kemudahan ini juga jelas terlihat dan dirasakan oleh berbagai pihak. Produktivitas yang terus dikejar menimbulkan penyakit psikosomatik, pencemaran terhadap unsur panca maha bhuta seperti udara, air, tanah, ruang dan suhu juga memunculkan berbagai penyakit pernapasan, pencernaan, ginjal, hati, kanker dan sebagainya yang belum tentu dapat ditangani dengan baik (Nala, 2006).

Timbulnya berbagai penyakit akhirnya mendorong masyarakat untuk mencari berbagai pengobatan. Namun pengaruh kemajuan ilmu kedokteran medis yang kuat menjadikan masyarakat menggunakan obat-obatan kimia, padahal zat-zat kimia di dalam obat yang dikonsumsi akan menimbulkan komplikasi dalam tubuh dan sangat membahayakan, sehingga memunculkan kembali jenisjenis gangguan kesehatan lain dalam tubuh manusia (Sakri, 2012). Belenggu gaya hidup yang serba instan dan timbulnya berbagai jenis penyakit baru menyebabkan masyarakat pada akhirnya mencari alternatif untuk menjaga kesehatannya, salah satunya yaitu dengan pola hidup kembali kepada alam (back to nature) untuk mencari sumber pengobatan yang aman, alami, tidak berdampak buruk bagi kesehatan, serta ramah lingkungan. Kecenderungan back to nature dengan memanfaatkan obat-obatan tradisional yang memakai bahan alami seperti tumbuhan kemungkinan efek negatifnya dalam jangka panjang amat kecil dibandingkan dengan menggunakan obat sintetis buatan pabrik. Selain itu, kecenderungan baru untuk memperoleh kesehatan dan kebugaran namun tetap praktis terkait dengan back to nature yakni mengkonsumsi makanan serta minuman organik (Wiarto, 2013).

Pada dasarnya apa yang dikonsumsi hendaknya harus memiliki lima fungsi utama, yaitu: (1) menyokong pertumbuhan tubuh; (2) sumber energi dan tenaga; (3) memelihara jaringan tubuh dan merevitalisasi sel-sel yang rusak; (4) mengatur metabolisme dan keseimbangan mineral di dalam cairan tubuh; serta (5) sebagai antioksidan dan antibodi tubuh. Selain itu harus memiliki lima unsur penting yang 
dibutuhkan tubuh, yaitu: karbohidrat, protein, lemak, mineral, dan vitamin. Serta terdapat dua jenis zat non gizi yaitu air dan oksigen (Wijaya, 2009).

Kampanye mengkonsumsi buah dan sayuran organik semakin menunjukkan eksistensinya, sehingga kini menjamur pula bisnis makanan dan minuman organik di tengah-tengah masyarakat. Kecendrungan masyarakat mengkonsumsi makanan serta minuman organik merupakan salah satu alternatif masyarakat untuk kembali ke alam atau back to nature agar mendapatkan kesehatan. Penggunaan tanaman sebenarnya bukan hanya sebagai makanan dan minuman namun ada pula digunakan sebagai obat tradisional yang merupakan cerminan dari tindakan kembali ke alam atau back to nature sebagai pilihan alternatif yang saat ini diminati masyarakat (Pratama, Aditya, \& Firzatullah, 2013). Senada dengan hal itu, menurut Soeparto (1999) saat ini manusia sudah diajak kembali kepada alam dengan memusatkan perhatian pada tumbuh-tumbuhan berkhasiat yang diolah dan dipergunakan untuk mempertahankan kesehatan.

Tumbuh-tumbuhan sebagai bahan obat telah menjadi penerapan pelayanan kesehatan di Indonesia jauh sebelum penduduk Indonesia mengenal pelayanan kesehatan modern (Endang S, 2000). Dalam ilmu kesehatan Ayurweda dijelaskan bahwa daun adalah salah satu bagian tumbuhan yang dapat dipakai sebagai bahan obat untuk memulihkan kesehatan disamping bahan lainnya seperti kulit pohon, akar, bunga dan buah (Lad \& Svoboda, 2007).

Teknik pengobatan Ayurweda sebagai cerminan gerakan kembali ke alam tidak menambahkan bahan sintetis dalam proses pembuatan obatnya (Dash \& Ramaswamy, 2006). Ayurweda juga merupakan akar dari pengobatan Usada yang ada di Bali terbukti dari banyaknya pengetahuan pengobatan dalam lontar Usada yang berasal dari kitab Ayurweda (Nala, 2001). Pengobatan tradisional Bali atau Usada memiliki pengetahuan pengobatan yang mempergunakan tumbuhan sebagai bahan obat, diramu sedemikian rupa sehingga dapat diminum sebagai loloh (Prastika, 2013).

Saat ini loloh menjadi salah satu minuman tradisional yang banyak dikonsumsi oleh masyarakat, khususnya masyarakat Bali yang dekat dengan obat-obatan tradisional. Salah satu loloh yang banyak beredar dipasaran dan dikonsumsi oleh masyarakat adalah loloh don cemcem. Loloh merupakan minuman kesehatan atau sering disebut jamu oleh masyarakat Indonesia (Suparta, 2010). Dalam bahasa Indonesia loloh disebut sebagai jamu yang juga merupakan sebutan untuk obat tradisional dari Indonesia yang dibuat dari bahan tumbuhan meliputi rimpang, daun, kulit batang dan buah yang semuanya merupakan bahan alami (Sakri, 2012).

Loloh don cemcem berasal dari bahan baku daun cemcem (Spondias pinnata (Lf) Kurz), dibuat dengan cara tradisional seperti pembuatan jamu pada umumnya disertai beberapa bahan tambahan lain yang dapat memperkuat rasa dari loloh tersebut. Masyarakat selalu mencari loloh untuk melepaskan dahaga saat haus dan yakin jika mengkonsumsi Loloh don cemcem maka badan akan terasa lebih segar, bugar serta dapat menghilangkan panas dalam. Loloh don cemcem juga dipercaya menyehatkan, ditambah rasa loloh yang khas dan enak. Kini Loloh don cemcem dapat diminum secara praktis sebab telah tersedia dalam kemasan botol. Fenomena ini jelas terlihat dari yang awalnya konsumen loloh don cemcem ini 
hanya wisatawan yang berkunjung ke Desa Penglipuran, Kabupaten Bangli Provinsi Bali yang merupakan sentra produksi loloh don cemcem, kini konsumennya sudah hampir di seluruh Bali termasuk di restoranrestoran yang ada di Bali dan juga dijual pada pameran di ajang Pesta Kesenian Bali pada tiap tahunnya serta wisatawan domestik dan mancanegara yang berkunjung ke Bali (Yudistirani, 2019).

Keyakinan masyarakat yang tinggi serta semakin menjamurnya pedagang Loloh don cemcem merupakan fenomena sosial mengenai perilaku, tindakan, persepsi, keyakinan dan relasi masyarakat dalam meningkatkan kesehatannya. Masyarakat yang terdiri dari banyak individu dipastikan memiliki alasan tersendiri untuk memilih minuman tersebut sebagai penunjang kebugaran dan kesehatannya.

\section{PEMBAHASAN}

\subsection{Klasifikasi Cemcem}

Don cemcem atau daun cemcem yang biasa dipakai loloh di pasaran berasal dari tumbuhan kecemcem yang memiliki nama latin Spondias pinnata (Lf) Kurz. Kecemcem memiliki nama latin Spondias pinnata (Lf) Kurz sesuai dengan hasil penelitian Wrasiati, Antara, \& Wartini (2014), salah satu tanaman tropis yang digunakan sebagai minuman tradisional di Bali adalah kecemcem atau cemcem yang bernama latin Spondias pinnata (Lf) Kurz.

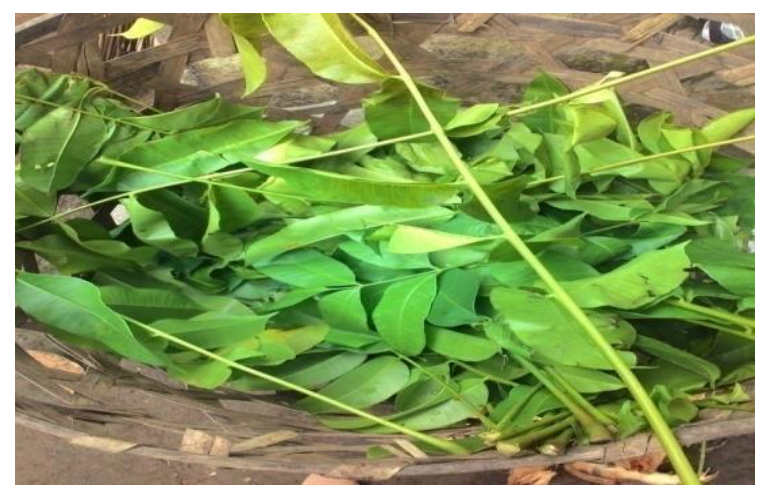

Gambar 1. Daun Cemcem (Spondias pinnata (Lf) Kurz)

Sumber: Dokumen Pribadi

Menurut Saimah (2010: 8) tanaman Spondias pinnata (Lf) Kurz memiliki klasifikasi sebagai berikut:

$\begin{array}{ll}\text { Kingdom } & : \text { Plantae } \\ \text { Divisi } & : \text { Spermatophyta } \\ \text { Sub Divisi } & : \text { Angiospermae } \\ \text { Kelas } & : \text { Dicotyledoneae } \\ \text { Ordo } & : \text { Sapindales } \\ \text { Familia } & : \text { Anacardiaceae } \\ \text { Genus } & : \text { Spondias }\end{array}$

Spesies : Spondias pinnata (Lf) Kurz 
Lebih lanjut dikatakan Spondias pinnata (Lf) Kurz merupakan tanaman yang tinggi pohonnya $\pm 20 \mathrm{~m}$. Batang berbentuk tegak, bulat, berkayu, permukaan halus, percabangan simpodial, putih kehijauan. Daun majemuk, lonjong, menyirip ganjil, tersebar, pangkal runcing, ujung meruncing, pertulangan menyirip, tepi rata, panjang 5-8 cm, lebar 3-6 cm, berwarna hijau. Bunga majemuk, bentuk malai, di ketiak daun dan diujung cabang, panjang 24-40 cm, kelopak panjang $\pm 5 \mathrm{~cm}$, ungu, benang sari delapan, kuning, mahkota empat sampai lima, lanset, putih, kekuningan. Buah buni, lonjong, berdaging, diameter $\pm 5 \mathrm{~cm}$, berserat, hijau, kekuningan. Biji bulat, berserat kasar-kasar, putih kekuningan, akar tunggang berwarna coklat tua.

\subsection{Cara membuat loloh don cemcem}

Loloh atau dalam bahasa Indonesia berarti jamu dikenal dalam berbagai bentuk yaitu cairan, rebusan dan serbuk. Loloh merupakan obat tradisional yang telah dikonsumsi secara turun temurun oleh masyarakat Indonesia khususnya Bali. Namun pada perkembangannya konsumsi loloh sempat mengalami pasang surut yang disebabkan kecenderungan masyarakat untuk mengkonsumsi obat-obatan modern. Secara umum loloh yang dikonsumsi masyarakat merupakan loloh segar yang diolah dari bahan yang masih segar dan segera dikonsumsi ketika selesai pengolahannya.

Menurut Saimah (2010) secara umum pengolahan daun cemcem sampai menjadi loloh, dapat dikatakan sebagai berikut: (1) Mencuci tangan dan menyiapkan bahan berupa daun cemcem (Spondias pinnata (Lf) Kurz) dan air sebagai bahan baku serta garam, asam jawa (Tamarindus indica L.), gula merah, gula pasir, terasi bakar, cabe rawit (Capsicum frutescens L.) dan kelapa muda (Cocos nucifera L.) serta airnya sebagai bahan pendukung, (2) Siapkan alat-alat berupa penggiling daun, alat penyaring, wadah, sendok kayu dan botol kemasan, (3) Pengolahan loloh don cemcem dimulai dari membersihkan daun cemcem (Spondias pinnata (Lf) Kurz), menggiling daun lalu hasil gilingan ditambah air lalu diperas dan disaring, kemudian dicampurkan bahan-bahan pendukung seperti : cabe rawit (Capsicum frutescens L.), asam jawa (Tamarindus indica L.), gula merah, gula pasir, terasi bakar, serta garam dan aduk hasil campuran tersebut lalu disaring kembali, ditambahkan air kelapa dan siap dikemas ke dalam botol kemasan disertai tambahan buah kelapa (Cocos nucifera L.). Lebih lanjut dalam penelitiannya menjelaskan bahwa alat, bahan dan proses pembuatan loloh don cemcem di desa Tradisional Penglipuran Bangli dapat dipaparkan sebagai berikut:

Alat-alat yang diperlukan:

- Penggilingan

- Saringan

- Wadah atau baskom

- Drum 130 liter

- Botol penyimpanan $200 \mathrm{ml}$.

Bahan-bahan yang diperlukan: 
- Daun cemcem (Spondias pinnata (Lf) Kurz)

- Kelapa muda (Cocos nucifera L.) diserut kasar beserta airnya

- Gula merah

- Gula pasir

- Asam Jawa (Tamarindus indica L.)

- Garam

- Cabe rawit (Capsicum frutescens L.)

- Air
$: 10 \mathrm{~kg}$

: 8 butir

$: 8 \mathrm{~kg}$

$: 8 \mathrm{~kg}$

$: 1 / 2 \mathrm{~kg}$

$: 1 / 2 \mathrm{~kg}$

$: 1 / 4 \mathrm{~kg}$

: 130 liter

Cara membuat:

1. Daun cemcem (Spondias pinnata (Lf) Kurz) dicuci hingga bersih kemudian dihancurkan dengan penggilingan dengan dicampurkan air sedikit.

2. Setelah hancur, larutan daun cemcem (Spondias pinnata (Lf) Kurz) diremas-remas di dalam wadah atau baskom kemudian disaring dan diremas lagi sambil ditambah air sedikit sampai semua sarinya keluar.

3. Hasil dari saringan dimasukkan dalam drum kemudian ditambahkan air \pm 130 liter. Tambah gula merah, gula pasir, cabe rawit (Capsicum frutescens L.) yang dihaluskan, asam jawa (Tamarindus indica L.) dan garam.

4. Terakhir tambahkan air kelapa dan kelapa muda (Cocos nucifera L.) yang diserut kasar diadukaduk sampai tercampur sempurna.

5. Minuman Loloh don cemcem dimasukkan ke dalam botol untuk dikonsumsi serta dijual.

Dalam pembuatan jamu atau Loloh don cemcem, upaya penerapan personal hygiene sama dengan proses pengolahan makanan dan minuman karena pada dasarnya jamu tradisional juga bahan yang dikonsumsi masyarakat. Upaya-upaya untuk mencegah pencemaran terhadap produksi jamu yaitu: (1) Tangan dan bagian-bagiannya harus selalu dijaga kebersihannya dengan memotong kuku dan mencucinya serta tidak menggunakan kutek (2) Tidak merokok sewaktu mengolah jamu tradisional (3) Menutup luka yang terbuka dengan plester anti air (4) Tidak mengolah jamu saat menderita flu, demam, pilek atau sakit tenggorokan (5) Tidak bekerja ketika memiliki penyakit saluran cerna (6) Tidak bekerja ketika sakit muntah-muntah (7) Tidak bekerja ketika sakit kulit (8) Menggunakan pakaian yang bersih, sarung tangan, sepatu yang baik (Sutana \& Dwipayana, 2020).

\subsection{Manfaat loloh don cemcem bagi kesehatan}

Mengamati peranaannya yang jika telisik lebih dalam, loloh atau jamu memiliki banyak sekali khasiat terutamanya dalam menjaga kesehatan tubuh manusia. Jamu telah ada sejak zaman nenek moyang, tetapi tidak banyak data yang didokumentasikan secara tertulis. Seiring dengan dinamika dan perkembangan zaman, diperlukan kembali untuk meningkatkan kesadaran generasi bangsa untuk melestarikan budaya minum jamu untuk kesehatan (Sutana \& Dwipayana, 2020). 
Fenomena yang muncul bahwa masyarakat sangat antusias mengkonsumsi loloh don cemcem disebabkan karena adanya tanggapan (perilaku, persepsi, keyakinan dan partisipasi) oleh masyarakat bahwa Loloh don cemcem mampu menjaga kesehatan masyarakat. Adanya tanggapan tersebut muncul karena masyarakat memiliki upaya-upaya dalam menjaga dan meningkatkan kesehatannya. Sesuai dengan asumsi dasar pendekatan sosiologi kesehatan bahwa sosiologi kesehatan mengartikan tentang perilaku yang diambil untuk menjaga atau meningkatkan kesehatan oleh setiap individu yang terkait dengan kesehatan. Dalam hal ini dibuktikan dengan minum loloh don cemcem untuk mengobati penyakitpenyakit ringan. Adapun manfaat loloh don cemcem bagi kesehatan adalah sebagai berikut:

1. Meningkatkan nafsu makan.

Loloh don cemcem terdiri dari beberapa bahan pendukung, salah satunya adalah cabai rawit. Cabai rawit dapat menambah nafsu makan. Lebih lanjut disebutkan bahwa cabai rawit mengandung vitamin A sebanyak 11.050 SI sehingga ampuh sebagai perangsang nafsu makan. Selain itu, cabai rawit juga memiliki kandungan kimia berupa capsaicin yang bersifat stomakik yakni berfungsi menambah selera makan. Senyawa flavonoid dalam daun cemcem dapat membantu menambah selera makan (Wijayakusuma, Daliamartha, \& Wirian, 1996). Selain itu, dengan adanya komponen asam juga dapat dipergunakan sebagai penambah nafsu makan, serta kelapa pun dapat menambah selera makan pada seseorang (Sakri, 2012).

2. Meringankan batuk kering dan memperlancar buang air kecil.

Selain menambah nafsu makan, loloh don cemcem juga dapat meringankan batuk kering. Hal ini disebabkan oleh daun cemcem tersebut memiliki senyawa saponin, flavonoid dan tanin yang dapat dipakai sebagai obat batuk kering (Saimah, 2010). Mengkonsumsi loloh don cemcem juga dapat menyebabkan buang air kecil menjadi lancar. Hal ini dikarenakan oleh senyawa tanin dalam daun cemcem memiliki efek diuretik sehingga dapat melancarkan buang air kecil.

3. Menurunkan Hipertensi.

Hipertensi merupakan salah satu penyakit yang banyak diderita oleh masyarakat Indonesia. Penyakit hipertensi juga sering disebut dengan penyakit silent killer karena penyakit ini dapat menyebabkan kematian secara tiba-tiba pada penderitanya. Dalam loloh don cemcem terkandung senyawa flavonoid yang dihasilkan dari daun cemcem itu sendiri. Senyawa flavonoid ini berfungsi sebagai antioksidan yang sangat berguna untuk menurunkan tekanan darah pada penderita hipertensi. Selain itu, efek diuretik yang dihasilkan setelah mengkonsumsi loloh don cemcem juga berfungsi menurunkan tekanan darah pada penderita hipertensi (Soeryoko, 2010).

4. Meredakan panas dalam dan menambah cairan tubuh.

Panas dalam merupakan penyakit yang disebabkan oleh suhu panas yang berlebih pada sistem pencernaan. Ketika mengkonsumsi makanan yang mengandung banyak minyak, maka akan memicu timbulnya penyakit panas dalam ini. Kandungan vitamin $\mathrm{C}$ dan asam pada loloh don cemcem bermanfaat untuk menghilangkan panas dalam. Hal ini karena asam memiliki efek sejuk dan segar. Selain itu kelapa 
juga dapat menambah cairan dan mineral sehingga siapa pun yang mengkonsumsi buah kelapa akan merasa segar kembali (Wijayakusuma, Daliamartha, \& Wirian, 1996).

5. Melancarkan buang air besar dan menjaga kesehatan usus.

Makanan maupun minuman yang kita konsumsi sudah barang tentu akan dicerna oleh organ perncernaan kita. Kandungan asam pada loloh don cemcem dapat berfungsi sebagai obat pencahar yaitu melancarkan buang air besar (Wijayakusuma, Daliamartha, \& Wirian, 1996). Selain itu kandungan kelapa pada loloh don cemcem berfungsi sebagai obat diare sehingga dapat mengatasi permasalahan pada buang air besar. Lebih lanjut senyawa tanin dalam daun cemcem yang memiliki sifat astringent yaitu berfungsi melapisi mukosa usus khususnya usus besar dan mengecilkan selaput lendir usus serta sebagai penyerap racun dan menggumpalkan protein. Oleh karena itu senyawa tanin dapat dipergunakan sebagi obat diare (Lestari, 2013).

\section{PENUTUP}

Cemcem atau kecemcem dalam Bahasa Indonesia merupakan tumbuhan asli Indonesia yang memiliki nama latin Spondias pinnata (Lf) Kurz. Pohon cemcem memiliki tinggi $\pm 20 \mathrm{~m}$. Batang berbentuk tegak, bulat, berkayu, permukaan halus, percabangan simpodial, putih kehijauan. Cara membuat loloh don cemcem pada umumnya sama dengan cara pembuatan jamu tradisional. Secara umum, pengolahan daun cemcem sampai menjadi loloh, dimulai dari proses penyiapan alat dan bahan. Kemudian dilanjutkan dengan proses meramu bahan tersebut hingga menjadi loloh don cemcem sampai pada akhirnya ke proses pengemasan. Dalam pengolahan daun cemcem hingga menjadi loloh, higyene personal merupakan salah satu faktor penting yang tidak boleh dilupakan agar loloh yang diolah dapat memberikan manfaat kepada yang mengkonsumsinya.

Sama seperti pada umumnya obat tradisional yang dalam hal ini berbentuk jamu, loloh don cemcem juga memiliki beberapa manfaat yang berasal dari kandungan senyawa daun cemcem itu sendiri maupun dari bahan-bahan pendukungnya. Beberapa manfaat loloh don cemcem bagi kesehatan tubuh manusia diantaranya: (a) Meningkatkan nafsu makan; (b) Meringankan batuk kering dan memperlancar buang air kecil; (c) Menurunkan Hipertensi; (d) Meredakan panas dalam dan menambah cairan tubuh; serta (e) Melancarkan buang air besar dan menjaga kesehatan usus.

\section{DAFTAR PUSTAKA}

Dash, V. B., \& Ramaswamy, S. (2006). Ayurveda Ilmu Pengobatan Tradisional India. Surabaya: Paramita.

Endang S. (2000). Membuat Jamu Beras Kencur. Yogyakarta: Kanisius.

Lad, D. V., \& Svoboda, R. E. (2007). Ayurveda. Surabaya: Paramita.

Lestari, N. A. (2013). Makalah Farmakognosi-Tanin. Retrieved from Academia.Edu: http://www.academia.edu/7268353/Makalah_Farmakognosi_-_Tanin. 
Nala, N. (2001). Ayurveda Ilmu Kedokteran Hindu. Denpasar: Upada Sastra.

Nala, N. (2006). Aksara Bali Dalam Usadha. Surabaya: Paramita.

Prastika, I. (2013). "Usadha" Pengobatan Tradisional Bali. Retrieved from unhi.ac.id/file/Artikel/Usada,-Pengobatan_Tradisional_Bali_Prastika-1.pdf.

Pratama, B., Aditya, \& Firzatullah, D. R. (2013). Pengobatan Berbagai PenyakitDengan Metode Herbal Kembali Ke Alam. Surabaya: Pustaka Media.

Saimah. (2006). Kualitas Loloh Kecemcem di Penglipuran Bangli Ditinjau dari Kandungan Total Bakteri, Mpn Coliform dan Escherichia coli (Skripsi). Denpasar: Universitas Hindu Indonesia.

Sakri, F. (2012). 1001 Khasiat \& Manfaat Jamu Godog Untuk Segala Macam Penyakit. Yogyakarta: Diandra Pustaka Indonesia.

Soeparto, S. S. (1999). Jamu Jawa Asli. Jakarta: Pustaka Sinar Harapan.

Soeryoko, H. (2010). Tanaman Obat Terpopuler Penurun Hipertensi. Yogyakarta: CV. Andi Offset.

Suparta, I. K. (2010). Kamus Bahasa Bali. Denpasar: CV. Kayumas Agung.

Sutana, I. G., \& Dwipayana, A. P. (2020). Perilaku Konsumsi Jamu Tradisional Di Tengah Pandemi Covid-19. In Poniman, \& J. Simarmata, Covid-19: Perspektif Agama Dan Kesehatan (pp. 41-68). Denpasar: Yayasan Kita Menulis.

Wiarto, G. (2013). Budaya Hidup Sehat. Yogyakarta: Gosyen Publishing.

Wijaya, P. S. (2009). Makanan Satwik Dan Kesehatan. Surabaya: Paramita.

Wijayakusuma, H., Daliamartha, S., \& Wirian, A. S. (1996). Tanaman Berkhasiat Obat di Indonesia Jilid II. Jakarta: Pustaka Kartini.

Wrasiati, L. P., Antara, N. S., \& Wartini, N. M. (2014). Karakteristik Instan Bubuk Cemcem (Spondiaz pinnata Lf Kurz). Media Ilmiah Teknologi Pangan (Scientific Journal of Food Technology), 1(1), 58-70.

Yudistirani, I. (2019). Loloh Cemcem Minuman Bali. Retrieved from https://bali.idntimes.com/food/dining-guide/irma/loloh-cemcem-minuman-bali-agp-c1c2regional-bali/5 